\title{
PENGARUH MODEL PEMBELAJARAN DISCOVERY LEARNING MENGINTERPRETASI TEKS LAPORAN HASIL OBSERVASI PESERTA DIDIK KELAS $X$
}

\author{
Dewi Mulyati' ${ }^{1,}$ Hariyadi $^{2}$ \\ Guru SMA Muhammadiyah 1 Palembang' ${ }^{1,}$ Dosen FKIP UM Palembang ${ }^{2}$ \\ Jalan Jenderal Ahmad Yani \\ Sur-el: dewi88mulyati@gmail.com ${ }^{1}$, haryadi fkipump@yahoo.co.id ${ }^{2}$
}

Article info

Article history:

Received: 24/10/2018

Revised :25/10/2018

Accepted: 7/11/2018

Keywords:

interpretation, report

text, observation

results

Kata

Kunci:nterpretasi,teks laporan, hasil

observasi

\section{A B S T R A C T}

The background is that students find it difficult to interpret the report text. The problem of how learning interprets the text of the observation report on class $X$ students. The purpose of this study is describe the learning planning of interpreting the text of the observation report on class $X$ students. This research method is classroom action research. The results of the study are as follows. (1) Based on the initial information questionnaire, it is known that 99.00\% of class X students find it difficult to interpret the text of the observation report. (2) the average pre-cycle score shows that learning to interpret the text content of the observation report of class $X$ is still lacking, namely 51.41. (3) The increase in the first cycle was 5.22. (4) Cycle II experienced an increase in score of 4.00. This increase is influenced by discovery learning and the problem of basic learning.

Latar belakang dalam penelitian ini adalah peserta didik kesulitan minginterprestasi teks laporan. Rumuasan masalah bagaimanakah pengaruh model pembelajaran discovery learning terhadap hasil belajar menginterpretasi teks laporan hasil observasi pada peserta didik kelas X. Tujuan penelitian ini adalah mendeskripsikan perencanaan pembelajaran menginterpretasi teks laporan hasil observasi pada peserta didik kelas X. Metode penelitian ini adalah penelitian tindakan kelas. Hasil penelitian adalah sebagai berikut. (1) Berdasarkan angket informasi awal diketahui bahwa 99,00\% peserta didik kelas $X$ kesulitan menginterprestasi isi teks laporan hasil observasi. (2) Skor rata-rata prasiklus menunjukan bahwa pembelajaran menginterprestasi isi teks laporan hasil observasi kelas $X$ masih kurang, yaitu51,41. (3) Peningkatan yang terjadi pada siklus I sebesar 5,22. (4) Siklus II mengalami peningkatan Skor sebesar 4,00. 


\section{JURNAL ILMIAH \\ BINA EDUKASI \\ ISSN 1979-8598e-ISSN: $2655-8378$ \\ http://journal.binadarma.ac.id/index.php/jurnalbinaedukasi \\ Vol. 11, No. 2, Desember 2018, 75-85}

\section{PENDAHULUAN}

Latar belakang dalam penelitian ini menunjukkan bahwa peserta didik mengalami kesulitan dalam menginterpretasi teks laporan. Salah satu pembelajaran bahasa Indonesia yang harus diajarkan oleh guru kepada peserta didik adalah menginterpretasi, khususnya pada teks laporan hasil observasi. Teks laporan hasil observasi memiliki peranan penting bagi peserta didik, di dalam teks tersebut fakta-fakta disajikan berdasarkan hasil pengamatan. Melalui teks laporan hasil observasi peserta didik dapat memperoleh, baik sejumlah informasi, pengetahuan, maupun wawasan yang luas. Informasi yang terdapat di dalam paragraf-paragraf tersebut diklasifikasikan ke dalam jenis laporan. Karakteristik sebuah laporan berupa teks bertujuan untuk memberikan berbagai informasi dan pengetahuan yang sejelas-jelasnya kepada pembaca.Seseorang yang mampu menguasai keempat keterampilan itu akan mampu berkomunikasi dengan baik. Bahasa mencerminkan pikirannya. Semakin terampil orang berbahasa, semakin cerah dan jelas pula pikirannya (Tarigan, 2013:1).

Pembelajaran bahasa Indonesia yang tertera dalam silabus salah satunya yait menginterpretasi teks laporan hasil observasi yang diajarkan pada jenjang SMA/MA/SMK/MAK yakni terdapat pada KI 4 Mengolah, menalar, dan menyaji dalam ranah konkret dan ranah abstrak terkait dengan pengembangan yang dipelajarinya di sekolah secara mandiri, dan mampu menggunakan metode sesuai kaidah keilmuan (Kurniasih dan Berlin Sani, 2014). KD 4.1 Menginterpretasi tek laporan hasil observasi baik secara lisan maupun tulisan.Teks laporan hasil observasi merupakan salah satu materi pelajaran Bahasa Indonesia kelas X semester gazal. Teks laporan hasil observasi dapat diartikan sebagai teks yang berisi laporan hasil pengamatan siswa secara faktual (nyata) kemudian siswa memperoleh sejumlah pengetahuan atau wawasan dan informasi berdasarkan fakta yang ada (Kemendikbud, 2013).

Ada beberapa penelitian yang relevan, yaitu sebagai berikut. Pertama, metode "ThinkPair-Share” pada pembelajaran menulis teks Laporan Hasil Observasi di kelasXMIPASMANegeri1Pakemdapat meningkatkan kualitas proses pembelajaran (Kusmarmi, 2015). Kedua, Kemampuan menulis teks laporan hasil observasi pada siswa kelas VII SMP Negeri 13 Bandar-Lampung indikator struktur teks laporan hasil observasi tergolong dalam kategori baik sekali (Dini, dkk., 2015). Ketiga, pembelajaran dengan penggunaan media gambar maka dapat disimpulkan bahwa penerapan pembelajaran ini dapat meningkatkan hasil belajar siswa pada pelajaran IPS kelas IV SD Inpres III Tada (Ritna, 2016). Keempat, penggunaan metode PAILKEM dapat meningkatkan hasil pembelajaran menyusun teks laporan hasil pengamatan siswa kelas V11/1 MTsN (Sriastuti dan Fahruddin Hnafi, 2017). Solusi untuk 
mengatasi pembelajaran adalah dengan memakai strategi pemodelan, yaitu Discovery leaarning dan problem basic learning.

\section{METODOLOGI PENELITIAN}

Jenis penelitian adalah penelitian tindakan kelas (classroom action research). Penelitian tindakan kelas merupakan penerapan penemuan fakta pada pemecahan masalah dalam situasi sosial dengan pandangan untuk meningkatkan kualitas (Suwandi, 2015). Penelitian tindakan kelas melalui beberapa tahapan, yaitu: perencanaan tindakan (planning), penerapan tindakan (action), mengobservasi dan mengevaluasi proses dan hasil belajar (observation and evaluation), melakukan refleksi (reflecting), dan seterusnya hingga kriteria keberhasilan tercapai (Tim Penyusun, 2018).

\section{a. Waktu dan Tempat}

Tempat penelitian tindakan kelas adalah kelas X IPA Olimpiade SMA Muhammadiyah 1 Palembang yang beralamat di Jalan Balayuda No. 21 A Palembang. Penelitian ini akan dilaksanakan pada semester gazal Tahun Ajaran 2018/2019. Waktu perencanaan penelitian dilaksanakan pada bulan Agustus 2018. Adapun pelaksanaan tindakan sesuai dengan jadwal pelajaran. Setiap minggunya pelajaran Bahasa Indonesia dilaksanakan 4 jam pelajaran hari Selasa dan Jumat.

\subsection{Target/Sasaran}

Target atau sasaran pembelajaran teks laporan hasil observasi agar peserta didik dapat mengatasi permasalahan yang ada di lapangan. Di samping itu, dapat mengambil sebuah keputusan yang lebih efektif berdasarkan informasi, pengetahuan, dan wawasan secara faktual sehingga dapat bermanfaat bagi peserta didik untuk kedepannya. Tugas guru adalah bukan sekedar membelajarkan siswa melainkan guru dapat merencanakan, melaksanakan, dan mengevaluasi pembelajaran. pendidik harus menerapkan strategi yang dapat mempermudah peserta didik dalam memahami teks laporan hasil observasi, sehingga dalam berdiskusi peserta didik lebih mudah memecahkan masalah dan mengambil sebuah keputusan terhadap hal yang sudah pernah diperoleh sebelumnya yakni dengan mempelajari teks laporan hasil observasi. Kegiatan yang dilakukan pendidik sangat bergantung pada perencanaan, pelaksanaan, dan 


\section{JURNAL ILMIAH}

BINA EDUKASI

ISSN 1979-8598e-ISSN: 2655-8378

http://journal.binadarma.ac.id/index.php/jurnalbinaedukasi

Vol. 11, No. 2, Desember 2018, 75-85

penilaian. Namun, peneliti belum mengetahui bagaimana tahapan pembelajaran yang akan diterapkan dalam membelajarkan peserta didik pada pembelajaran menginterpretasi teks laporan hasil observasi.

\subsection{Subjek Penelitian}

Peneliti memilih di SMA Muhammadiyah 1 Palembang karena sekolah tersebut merupakan salah satu sekolah yang memiliki akreditasi A di Kota Palembang dan merupakan SMA yang menggunakan kurikulum 2013 revisi 2016. Di samping itu, banyak meraih prestasi dalam bidang akademik, seni, dan olahraga. Selain itu, memiliki sarana dan prasarana yang lengkap.

\subsection{Prosedur}

Prosedur penelitian melalui beberapa tahap, yaitu perencanaan, pelaksanaan tindakan, pengamatan, dan refleksi. Tahap perencanaan dilakukan setelah dan sebelum tindakan diberikan kepada peserta didik. Tahap pelaksanaan tindakan peneliti menerapkan perencanaan yang sudah disusun bersama dengan pendidik. Pendidik melakukan proses pembelajaran sesuai dengan perencanaan yang telah disusun sebelumnya, yaitu dengan menggunakan strategi pemodelan. Tahap pengamatan proses pembelajaran berlangsung, peneliti mengamati segala yang dilakukan peserta didik di dalam kelas yang berkaitan dengan kegiatan kemampuan menginterprestasi. Refleksi dilakukan oleh peneliti dan guru untuk menilai tingkat keberhasilan pembelajaran menginterprestasi teks laporan hasil observasi menggunakan strategi pembelajaran pemodelan. Kekurangan dan kendala selama penelitian berlangsung akan didiskusikan dan akan dicari solusinya sebagai pijakan bagi siklus selanjutnya. Kegiatan pada siklus selanjutnya mengikuti prosedur pada siklus 1 , meliputi perencanaan, tindakan, observasi, dan refleksi.

\subsection{Instrumen}

Instrumen penelitian ini meliputi tes, angket, catatan lapangan, dan dokumentasi. Dalam penelitian ini, digunakan teknik pengumpulan data berupa teknik tes dan nontes. 


\section{JURNAL ILMIAH \\ BINA EDUKASI \\ ISSN 1979-8598e-ISSN: 2655-8378 \\ http://journal.binadarma.ac.id/index.php/jurnalbinaedukasi \\ Vol. 11, No. 2, Desember 2018, 75-85}

\subsection{Teknik Analisis Data}

Penelitian ini menggunakan teknik analisis kualitatif deskriptif dan kuantitatif. Analisis kualitatif digunakan untuk menganalisis data kualitatif yang berupa angket, catatan lapangan, dan wawancara. Data semacam ini diperoleh dengan cara pengamatan. Informasi yang diperoleh serta permasalahan yang muncul dalam implementasi tindakan, kemudian dibahas, didiskusikan, dipelajari, dan dipecahkan bersama antara peneliti dan guru sebagai kolaborator. Data kuantitatif diperoleh dari hasil tes menulis pada setiap siklusnya. Bentuk dari data ini berupa skor kemampuan teks laporan hasil observasi peserta didik. Skor ini berupa penilaian terhadap kualitas isi, organisasi penulisan, serta tata tulis dan ejaan dalam hasil tes menulis teks laporan hasil observasi siswa. Selanjutnya, dihitung rata-rata pencapaian skor siswa pada satu siklus, dan dibandingkan.

\section{HASIL DAN PEMBAHASAN}

\section{a. Peningkatan Proses Pembelajaran Menulis Teks Laporan Hasil Observasi dengan Menggunakan Strategi Pemodelan}

Peningkatan proses pembelajaran menginterprestasi isi teks laporan hasil observasi diamati dan dimonitoring berdasarkan pelaksanaan tindakan pembelajaran menginterprestasi isi teks laporan hasil observasi dengan menggunakan strategi pemodelan pada saat pratindakan sampai siklus II. Peningkatan proses juga diamati dari awal sampai akhir pembelajaran. Pada proses pembelajaran saat pratindakan, pendidik masih menggunakan metode ceramah sehingga pembelajaran kurang menarik peserta didik. Selain itu, peserta didik juga kurang antusias terhadapa materi yang disampaikan oleh pendidik. Pada awal kegiatan, pendidik mengawali dengan memberikan materi mengenaimenginterprestasi isi teks laporan hasil observasi. Interaksi hanya terjadi antara pendidik dengan peserta didik pada saat pendidik memberikan apersepsi. Sebagian besar peserta didi juga kurang memperhatikan penjelas yang disampaikan oleh pendidik. Pada akhir pembelajaran, pendidik memberikan tugas menginterprestasi isi teks laporan hasil observasi dengan judul teks yang telah ditentukan. Pesrta didik kurang antuasias saat diberi tugas.Saat proses pembelajaran, menunjukan kurangnya minat peserta didik terhadap pembelajaran menginterprestasi isi teks laporan hasil observasi. Hal tersebut dapat terlihat pada saat proses pembelajaran. Tindakan pembelajaranmenginterprestasi isi teks laporan hasil observasi dengan menggunakan strategi pemodelan dilanjutkan dengan siklus I dengan dua kali pertemuan. Pada pertemuan pertama,peserta didik diberikan contoh model teks yang berjudul 


\section{JURNAL ILMIAH \\ BINA EDUKASI \\ ISSN 1979-8598e-ISSN: 2655-8378 \\ http://journal.binadarma.ac.id/index.php/jurnalbinaedukasi \\ Vol. 11, No. 2, Desember 2018, 75-85}

"Buah Mengkudu". Selanjutnya, peserta didik mengamati dan mengidentifikasi kebahasaan dan struktur teks laporan hasil observasi. Akan tetapi, peserta didik terlihat belum antusias, dan kurang konsentrasi dalam proses pembelajaran. Oleh karena itu, peneliti melanjutkan pada pertemuan yang kedua.

Pada pertemuan kedua, peserta didik diajak untuk mengamati teks laporan hasil observasi. Peserta didik terlihat antusias, semangat, dan peserta didik terlihat mulai ada minat terhadap teks laporan hasil observasi. Tindakan pembelajaran menginterprestasi isi teks laporan hasil observasi dengan menggunakan strategi pemodelan dilanjutkan pada siklus II dengan dua pertemuan. Pada pertemuan pertama siklus II, peserta didik diberikan contoh model teks yang berjudul "Keberadaan Buah Pisang Di Indonesia". Selanjutnya, peserta didik mengamati dan mengidentifikasi kebahasaan dan struktur teks laporan hasil observasi. Peserta didik pada siklus II terlihat lebih antusias dan aktif. Oleh karena itu, peneliti melanjutkan pada pertemuan yang kedua. Pada pertemuan kedua, peserta didik diajak untuk mengamati teks laporan hasil observasi dan mencatat kebahasaan dan struktur teks laporan hasil observasi. Berdasarkan hasil pengamatan proses pembelajaran dan angket yang diberikan, terlihat peningkatan dalam proses pembelajaran. Minat, peserta didik terhadap pembelajaran mempengaruhi peningkatan kualitas dalam proses pembelajaran. Penggunaan strategi pemodelan dalam pembelajaran menginterprestasi isi teks laporan hasil observasi terbukti dapat meningkatkan kualitas proses pembelajaran, peserta didik di dalam kelas.

\section{b. Peningkatan Hasil Menulis Teks Laporan Hasil Observasi dengan Menggunakan Strategi Pemodelan}

Sebelum dilakukan tindakan peningkatan menginterprestasi isi teks laporan hasil observasi dengan menggunakan strategi pemodelan, diadakan tes pratindakan terlebih dahulu. Tes ini dilakukan untuk mengetahui kemampuan awal peserta didik dalam menginterprestasi isi teks laporan hasil observasi. Tes pratindakan ini berupa tugas menginterprestasi isi teks laporan hasil observasi dengan judul teks telah ditentukan. Hasil tes pratindakan yang telah dilakukan menunjukan semua peserta didik memperoleh skor rendah di bawah kriteria ketuntasan minimal yakni lebih dari 70. Namun setelah diberi tindakan menggunakan strategi pemodelan pada siklus I, peningkatan mulai terlihat walupun hanya beberapa peserta didik yang tuntas. Pada tindakan siklus II, peningkatan hasil menginterprestasi isi teks laporan hasil observasi dapatdikatakan berhasil atau meningkat walupun masih ada peserta didik yang belum sesuai dengan kriteria ketuntasan minimal. 
Tabel 1. Perolehan Nilai Pada Pratindakan, Siklus I dan Silkus II

\begin{tabular}{rlccc}
\hline No & Nilai & Pratindakan & siklus I & siklus II \\
\hline 1 & Nilai Rata-rata & 57,41 & 62,00 & 76,91 \\
2. & Nilai Teringgi & 70 & 70 & 88 \\
3 & Nilai Terendah & 50 & 60 & 70 \\
\hline
\end{tabular}

Berdasarkan tabel 1, peningkatan skor pada pratindakan sampai siklus II kelas X IPA Olimpiade SMA Muhammadiyah 1 Palembang dapat dilihat dari hasil skor rata-rata peserta didik 57,41 dengan skor terendah sebesar 50 dan skor tertinggi sebesar 70. Pada pembelajaran menginterprestasi isi teks laporan hasil observasi siklus I, penggunaan strategi pemodelan sangat memudahkan peserta didik dalam menginterprestasi isi. Hal tersebut terlihat pada tabel 5, hasil skor rata-rata peserta didik 62,00 dengan skor terendah sebesar 60 dan skor tertinggi sebesar 70. Namun, hasil tersebut belum sepenuhnya mencapai kriteria ketuntasan minimal yakni lebih dari 70 yang harus dicapai peserta didik.

Selanjutnya, pada pembelajaran siklus II mengalami peningkatan skor. Langkah pembelajaran menginterprestasi isi teks laporan hasil observasi pada siklus I sama dengan langkah pembelajaran pada siklus II sehingga langkah tersebut dapat meningkatkan menginterprestasi isi teks laporan hasil observasi peserta didik. Peningkatan tersebut dapat terlihat pada tabel 5 bahwa, skor rata-rata yang diperoleh sebesar 76,91 dengan skor terendah sebesar 70 dan skor tertinggi sebesar 88 . Berikut gambar peningkatan nilai rata-rata persiklus.

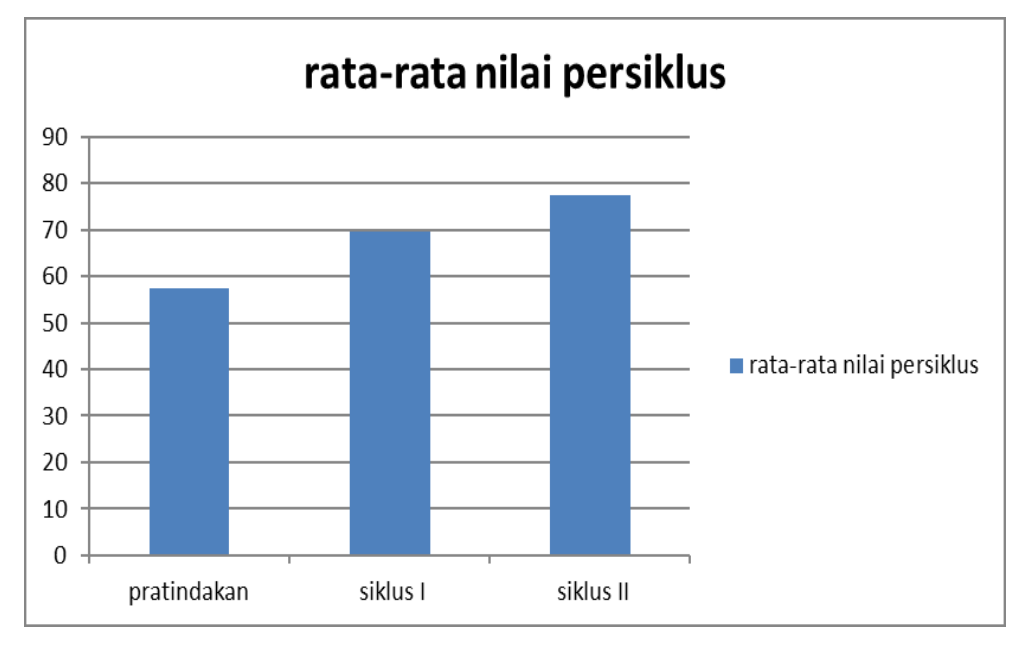

Gambar 1. Diagram Batang Nilai Rata-rata Pratindakan sampai Siklus II 


\section{JURNAL ILMIAH}

BINA EDUKASI

ISSN 1979-8598e-ISSN: $2655-8378$

http://journal.binadarma.ac.id/index.php/jurnalbinaedukasi

Vol. 11, No. 2, Desember 2018, 75-85

Menginterprestasi isi teks laporan hasil observasi peserta didik dari pratindakan (skor rata-rata adalah 57,41), pada siklus I (skor rata-rata adalah 62,00) telah mengalami peningkatan sebesar 9,22 dan siklus II (skor rata-rata adalah 76,91) mengalami peningkatan sebesar 7,80. Peningkatan tersebut mencapai 452terhitung dari nilai rata-rata menginterprestasi isi teks laporan hasil observasi saat pratindakan sampai siklus II.

Peningkatan juga terlihat dari skor tiap aspek yang mengalami peningkatan pada setiap tindakan yang dilakukan. Aspek kualitas isi pada saat pratindakan memperoleh skor rata-rata 19,83; pada siklus I dengan skor rata-rata 25,05 dan meningkat pada siklus II dengan skor ratarata 29,05. Aspek organisasi struktur pada pratindakan memperoleh skor rata-rata 12,25; pada siklus I dengan skor rata-rata 12,80 dan meningkat pada siklus II dengan skor rata-rata 16,22. Selanjutnya aspek kebahasaan memperoleh skor rata-rata 10,46; pada siklus I dengan skor ratarata 11,83 dan meningkat pada siklus II dengan skor rata-rata 11,25. Peningkatan tersebut terlihat pada tabel dan gambar berikut ini.

Tabel 2. Peningkatan Skor Tiap Aspek Persiklus

\begin{tabular}{rlccc}
\hline No & \multicolumn{1}{c}{ Aspek } & $\begin{array}{c}\text { Pratindakan } \\
\text { Ke Siklus I }\end{array}$ & $\begin{array}{c}\text { Siklus I Ke } \\
\text { siklus I }\end{array}$ & $\begin{array}{c}\text { Pratindakan Ke } \\
\text { siklus II }\end{array}$ \\
\hline $\mathbf{1}$ & Kualitas isi & $\mathbf{5 , 2 2}$ & $\mathbf{4 , 0 0}$ & $\mathbf{9 , 2 2}$ \\
$\mathbf{2 .}$ & $\begin{array}{l}\text { Organisasi } \\
\text { Penulisan }\end{array}$ & $\mathbf{0 , 5 5}$ & $\mathbf{3 , 9 7}$ & $\mathbf{4 , 5 2}$ \\
$\mathbf{3}$ & $\begin{array}{l}\text { Ejaan dan } \\
\text { Tata Tulis }\end{array}$ & $\mathbf{0 , 7 9}$ & $\mathbf{0 , 6 3}$ & $\mathbf{1 , 1 9}$ \\
& Jumlah & $\mathbf{6 , 5 6}$ & $\mathbf{8 6 . 0}$ & $\mathbf{1 4 , 9 3}$ \\
\hline
\end{tabular}

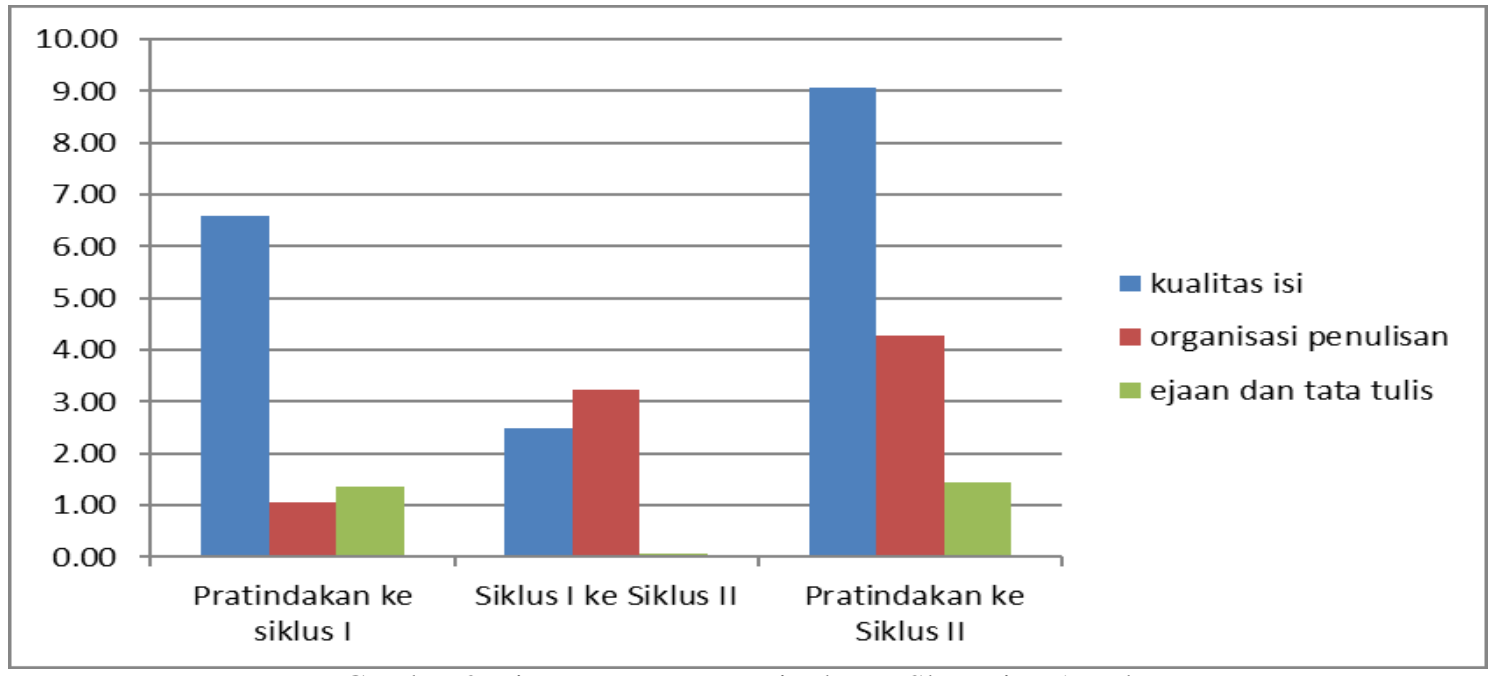

Gambar 2.Diagram Batang Peningkatan Skor Tiap Aspek 


\section{JURNAL ILMIAH}

BINA EDUKASI

ISSN 1979-8598e-ISSN: 2655-8378

http://journal.binadarma.ac.id/index.php/jurnalbinaedukasi

Vol. 11, No. 2, Desember 2018, 75-85

Peningkatan skor tiap aspek persiklus dikarenakan langkah-langkah penggunaan strategi pemodelan yang mudah dipahami dan mudah digunakan. Ada empat fase belajar dari model, yaitu fase perhatian (attentionalphase), fase retensi (retention phase), fase reproduksi (reproduction phase), dan fase motivasi (motivational phase). Sesuai dengan penelitian yang telah dilakukan sebelumnya, maka penelitian pembelajaran yang menggunakan strategi pemodelan ini dapat meningkatkan hasil menginterprestasi isi teks laporan hasil observasi peserta didik berdasarkan siklus I dan siklus II. Selain itu juga, peserta didik dapat meningkat hasil menginterprestasi isi teks laporan hasil observasi dari berbagai aspek di antaranya: aspek kualitas isi,aspek struktur dan aspek kebahasaan.

\section{c. Peningkatan Kemampuan Menulis Teks Laporan Hasil Observasi dengan Menggunakan Strategi Pemodelan}

Pembahasan hasil menginterprestasi isi menginterprestasi isi teks laporan hasil observasi terhitung dari pratindakan hingga tindakan siklus II. Hasil menginterprestasi isi teks laporan hasil observasi peserta didik berbeda-beda. Terdapat hasil menginterprestasi isi teks laporan hasil observasi dengan nilai tinggi sampai dengan hasil nilai terendah.

Teks laporan observasi adalah teks yang berfungsi untuk menggolongkan atau mengklasifikasikan informasi. Teks ini memiliki urutan yang logis tentang fakta tanpa keterlibatan personal peneliti. Teks laporan hasil observasi menginformasikan sesuatu yang hidup seperti hewan, tumbuhan atau benda mati seperti sungai, laut (Kemendikbud, 2013). Berdasarkan hal tersebut, peneliti pada pratindakan mengambil judul yang telah ditentukan sehingga peserta didik bisa menginterprestasi isi teks laporan hasil observasi sesuai pengetahuan dan kemampuan peserta didi. Pada siklus I, peneliti mengambil judul teksteks laporan hasil observasi "Wayang" dan pada siklus IImengambil judul teksteks laporan hasil observasi "Si Kecil Semut".

\section{SIMPULAN}

Berdasarkan hasil dan pembahasan penelitian dapat disimpulkan bahwa strategi pemodelan dapat digunakan untuk meningkatkan menginterprestasi isi teks laporan hasil observasi peserta didik kelas X IPA Olimpeade SMA Muhammadiyah 1 Palembang. 


\section{JURNAL ILMIAH}

BINA EDUKASI

ISSN 1979-8598e-ISSN: $2655-8378$

http://journal.binadarma.ac.id/index.php/jurnalbinaedukasi

Vol. 11, No. 2, Desember 2018, 75-85

Peningkatan yang terjadi setelah dilakukan tindakan meliputi peningkatan proses dan produk dideskripsikan.

\section{UCAPAN TERIMA KASIH}

Ucapan terima kasih disampaikan kepada Kemenristek Dikti melalui Program Hibah Revitilisasi LPTK: Penugasan dosen di sekolah.

\section{DAFTAR PUSTAKA}

Dini, Mutiara, dkk. (2015). "Kemampuan Menulis Teks Laporan Hasil Observasi Siswa Kelas VII SMPN 13 Bandarlampung." Jurnal Kata (Bahasa, Sastra, dan Pembelajarannya. Diakses arihttp://download.portalgaruda.org/article.php?article $=287651 \&$ val=7229\&title=KEMA MPUAN\%20MENULIS\%20TEKS\%20LAPORAN\%20HASIL\%20OBSERVASI $\% 20 \%$ 20SISWA\%20KELAS\%20VII\%20SMPN\%2013\%20BANDARLAMPUNG

Kemendikbud. (2013). Implementasi Kurikulum 2013. Jakarta: KementrianPendidikan dan Kebudayaan.

Kemendikbud. (2013). Impelementasi Kurikulum 2013 Penyusunan Rencana $\backslash$ Pelaksanaan Pembelajaran (RPP) SD/SMP/SMA/SMK. Jakarta:Kementrian Pendidikan dan Kebudayaan.

Kurniasih, Iman, dan Berlin Sani. (2014). Sukses Mengimplementasikan Kurikulum 2013. Surabaya: Kata Pena.

Kusmarmi. (2017). Peningkatan Kualitas Menulis Teks Laporan Hasil Observasi Kelas X MIPA SMA Negeri 1Pakem dengan Metode "Think-Pair-Share" diakses dari https://www.google.com/search?q=jurnal+ilmiah+guru\&ie=utf-8\&oe=utf$8 \&$ client=firefox $-\mathrm{b}$

Ritna. (2015). "Meningkatkan Hasil Belajar Siswa Kelas IV Dalam Pembelajaran IPS dengan Menggunakan Media Gambar di SD Inpres III Tada". Jurnal Kreatif Tadulako. Online. $\begin{array}{lllll}\text { Vo. } & 1 . & \text { No. } & 1 . & \text { Diakses }\end{array}$ http://id.portalgaruda.org/?ref=browse $\&$ mod=viewarticle $\&$ article $=157935$.

Sriastuti dan Fahruddin Hanafi. (2017). "Peningkatkan Keterampilan Menyusun Teks Laporan Hasil Pengamatan dengan Menggunakan Metode PAILKEM pada Siswa Kelas VII-1 MTSN 2 Kendari.” Dikases dari http://ojs.uho.ac.id/index.php/BASTRA/issue/view/371. 


\section{JURNAL ILMIAH}

BINA EDUKASI

ISSN 1979-8598e-ISSN: 2655-8378

http://journal.binadarma.ac.id/index.php/jurnalbinaedukasi

Vol. 11, No. 2, Desember 2018, 75-85

Suwandi, Sawiji. (2015). Penelitian Tindakan Kelas dan Penelitian Karya Ilmiah. Surakarta: Yuma Pustaka.

Tarigan, H. G. (2013). Keterampilan Berbahasa. Bandung: Angkasa.

Tim Penyusun. (2018). Pedoman Penelitian Tindakan Kelas (PTK). Palembang: Program Hibah Revitalisasi LPTK: Penugaasan Dosen di Sekolah dari Kemenristek Dikti. 